\title{
ТЕХНОЛОГІї ЕНЕРГОЗАБЕЗПЕЧЕННЯ
}

UDC 621.316 .11

A. S. Bondarchuk, Cand. Sc. (Tech.), Assoc. Prof., orcid.org/0000-0003-1232-5403
DOI: $10.29202 /$ nvngu/2018-1/20

Odesa National Polytechnic University, Odessa, Ukraine, e-mail: asb@te.net.ua

\section{INVESTIGATION OF THE INFLUENCE OF HIGHER HARMONIC CURVES ON THE CALCULATED LOADING OF THE NETWORK SOLAR ELECTRIC STATION WITH 30 kW POWER}

А. С. Бондарчук, канд. техн. наук, доц., orcid.org/0000-0003-1232-5403
Одеський національний політехнічний університет, м. Одеса, Україна, e-mail: asb@te.net.ua

\section{ДОСЛІДЖЕННЯ ВПЛИВУ СТРУМІВ ВИЩИХ ГАРМОНІК НА РОЗРАХУНКОВЕ НАВАНТАЖЕННЯ МЕРЕЖЕВОЇ СОНЯЧНОЇ ЕЛЕКТРОСТАНЦІЇ ПОТУЖНІСТЮ 30 кВТ}

Purpose. To estimate the magnitude of the influence of currents of higher harmonics on the electric load of an object with nonlinear electrical receivers, which receive electricity from the inverter of a network solar station.

Methodology. Measuring and modeling the processes in the electrical network revealed the presence of higher harmonics from the network solar power station, nonlinear electric devices and determined the effect of their impact on the electric load.

Findings. The depth of influence of currents of higher harmonics from the inverter of the network solar electric station, nonlinear electric devices on the magnitude of the electric load due to the additional heating of the current parts is estimated, which should be taken into account in each case in real conditions.

Originality. It lies in the experimental study of the spectrum of the higher harmonics of the inverter solar station, of the individual nonlinear electric receivers, the depth of their influence on increase in electric power losses in electric networks and electric devices, which cause their additional heating compared to the course of sinusoidal current.

Practical value. The resulting experimental measurements of the spectrum of higher harmonics of inverters, electrical receivers can serve as information for the creation of future databases. This can be used for defining the calculated loads, which will contribute to the prevention of overheating of electrical networks.

Keywords: network solar electric station, inverter, higher harmonics, nonlinear electrical receivers, calculated loading

Introduction. Widespread use of network solar electric station requires careful study of their impact on the parameters of the electrical network, the estimated load. This is due to the generation of higher harmonics by inverting DC from solar panels to alternating current of $50 \mathrm{~Hz}$ for the consumer. Professor Pivnyak G. G. notes that the energy of the Sun is not only inexhaustible and free, but, without doubt, more environmentally friendly than any type of human access to energy [1]. Professor Zhezhelenko I. V. warns that the distortion of the sinusoidal voltage, current leads to the negative influence of higher harmonics on the elements of electrical networks, electrical receivers, security system, and others. [2]. The scientist Prakhovnik A.V. emphasized that the network

(C) Bondarchuk A. S., 2018 stations enter the market of high energy, which provide electricity at the light part of the day, and at other times the power is received from the traditional network [3]. Professor Lezhniuk P.D. gives practical advice on simulating the loading of electrical networks by cubic splines, which is important for the power source power dissipation [4].

Analysis of the recent research and publications. Many scientific works are devoted to the harmonic analysis of the output voltage, the current of inverter sinks for various linear and nonlinear electric devices in real time [5]. The results of experiments with different types of inverters are presented [6]. Pulse-frequency modulation control systems for high harmonic filters are used to improve the quality of electric power [7]. The improvement of electric power quality is shown using a shunt active power filter [8]. Harmonic suppression devices based on inductive- 
capacitive elements are connected directly to the inverter [9]. With the current control of the inverter parameters, the harmonics of the lower order are eliminated [10].

Unsolved aspects of the problem. At the same time, the issues of the influence of distorted sinusoidal voltage, current on increasing the load of the electric network remain inadequate attention in the mentioned and similar studies. This is important for the proper choice of its section, switching and protective devices, and other elements of the power supply systems.

Objectives of the article. The purpose of the study is to analyze experimentally obtained spectrum of higher harmonics, which generates inverter of a network solar electric station, separate nonlinear electric receivers as well as to define processes in the system power supply, the degree of influence of harmonics on the additional estimated load of the electric network using mathematical modeling.

In order to achieve this goal, the following tasks were addressed in the work:

- to select a functioning network solar power station, the corresponding tools and schemes of organization of effective research for obtaining reliable results;

- to experimentally obtain the spectrum of higher harmonics generated by the inverter of the solar power station and individual nonlinear electrical devices;

- to carry out mathematical modeling of processes in the electric network from the inverter to the electric devices;

- to determine the degree of influence of higher harmonics on the estimated load of the solar power station due to the additional heating of the elements of the power supply;

- to provide recommendations for reducing the calculated load by suppressing the influence of higher harmonics on electromagnetic compatibility in power supply systems.

The experimental base of the study is based on the equipment of a $30 \mathrm{~kW}$ network solar power station, which operates in Odesa with coordinates $46^{\circ} 29^{\prime} 08^{\prime \prime} N$ and L $30^{\circ} 44^{\prime} 36^{\prime \prime}$.

The main elements of the network solar power station with a power of $30 \mathrm{~kW}$ and schemes for conducting research on a sunny day of September 4, 2017 are shown in Fig. 1.
Solar Panel TALESUN TP660R-260W polycrystalline (production of China), power $260 \mathrm{~W}$, voltage $\mathrm{x}$. $\mathrm{x}$ $37.8 \mathrm{~V}$, nominal current $8.51 \mathrm{~A}$, short-circuit current 9.16A, rated operating temperature from -45 to $60{ }^{\circ} \mathrm{C}$.

Network Inverter HUAWEI SUN2000-36KTL (manufactured in China) with a power output of $36 \mathrm{~kW}$, efficiency of no less than $98.6 \%$, operating temperature from -25 to $60{ }^{\circ} \mathrm{C}$. It contains 4 MPP trackers for leveling the heterogeneity effects of the power generation field, integrated intelligent monitoring of 8 strings, protective switching offsets, protection against overvoltage, short circuit, earth faults.

The study was carried out using Elspec Technologies' Elspec G4500 BLACKBOX Portable Elspec Technologies Portable (Israel's Production) Elspec Technologies Company.

Software for this analyzer, the PQSCADA Investigator from Elspec Technologies (Production of Israel), effectively processes a large number of parameters that are instantly displayed on the PC monitor.

Information that comes from one or more measurement points is displayed on one synchronized hour-angle axis. This allows you to observe a clear and instant graphical interpretation of the complex processes occurring on the network.

Presentation of the main research. The solar panels of the network solar station convert the radiation energy of the sun into a direct current, which, by means of the inverter, is converted into an alternating voltage of the electrical receivers, typically $0.38 / 0.22 \mathrm{kV}$.

The inverters make distortion of the sinusoidal voltage, which can be observed using the Elspec G4500 electricity quality analyzer, which joins the circle to the counter from the solar station (Fig. 1).

Acceptable values of voltage distortion, current are set by special standards for conversion devices, inverters used for solar power stations.

According to DSTU IEC 62040, the total harmonic voltage distortion coefficient of $T H D$ for inverters up to $8 \%$ is allowed, which is determined by the formula

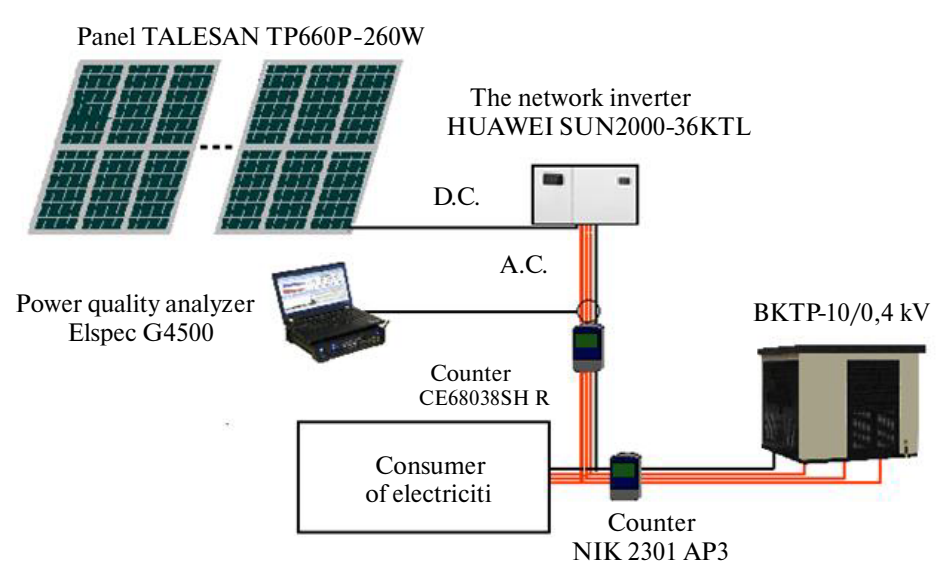

Fig. 1. The main elements of a network solar electric station with a power of $30 \mathrm{~kW}$ and the research scheme 
where $U_{i}$ is the mean square voltage value of the $i^{\text {th }}$ harmonic; $U_{1}$ is the basic harmonic.

The value of the individual coefficients of distortion of the $n^{\text {th }}$ voltage of the IHD inverter is determined in the following way

$$
I H D_{n}=\frac{U_{n}}{U_{1}} \cdot 100 \%
$$

where $U_{n}$ is the mean square value of the voltage $n^{\text {th }}$ harmonic.

The results of measuring these coefficients for the inverter showed that their values are within acceptable limits (Fig. 2).

However, additional losses $\Delta P_{n}$ relative to losses $\Delta P_{n o m}$ for the main frequency $(50 \mathrm{~Hz})$ in the electrical equipment in the presence of higher harmonics and interharmonics will depend on its parameters and the degree of voltage distortion is

$$
\frac{P_{n}}{\Delta P_{n o m}}=\sum_{n_{\max }}^{\infty} k_{n}\left(\frac{U_{n}}{U_{n o m}}\right)^{2},
$$

where $k_{n}$ is the coefficient dependent on the distortion of the voltage and electrical sine current.

Additional power losses $\Delta P_{A D}^{n}$ by the current of the $n^{\text {th }}$ harmonic in the induction motor are determined by the formula

$$
\Delta P_{A D}^{(n)}=3 I_{n}^{2}\left(r_{s t . n}+r_{r o t . n}^{2}\right)
$$

where $r_{\text {st.n }}, r_{\text {rot.n }}^{I}$ are active resistance of the stator and the rotor to the frequency of the $n^{\text {th }}$ harmonic.

The additional total electrical load, that is, the loss in asynchronous motors, caused by the generation of higher harmonics, is determined by the formula

$$
\Delta P_{A D}^{(n)}=\Delta P_{m . n o m} \sum_{n=2}^{m} K_{I(n)}^{2} \sqrt{n}
$$

where $K_{I(n)}$ is the multiplicity of the current of the $n^{\text {th }}$ harmonic to the first one.

The additional electric load, that is, the loss in transformers, caused by the generation of higher harmonics, is determined by the formula

$$
\Delta P_{T}^{(n)}=3 \sum_{n=2}^{m} I_{I(n)}^{2} r_{k} k_{(n)},
$$

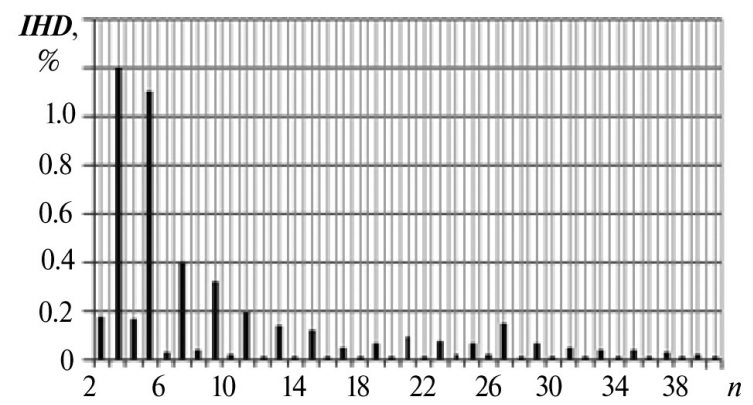

Fig. 2. The result of measuring the harmonic voltage spectrum at the output of the inverter where $r_{k}$ is the short circuit resistance of the transformer at the industrial frequency; $k_{(n)}$ is the coefficient taking into account the increase in the resistance of the shortcircuit over the higher harmonics so

$$
k_{(5)}=2,1, k_{(7)}=2,5, k_{(11)}=3,2, k_{(13)}=3.7 .
$$

However, when connecting nonlinear electrics such as air conditioners, PCs, fluorescent lamps, microwave ovens, and others to the inverter output, there will be further distortion of the voltage and current in the network.

An example of the study of the effect of higher harmonics current on the calculated electrical load of the conditioner SENSEI ECO-i FTE-23MR series [11-13] is given.

The diagram of the harmonics generated by this conditioner is shown in Fig. 3.

The magnitude of the power that causes the additional load of the wiring to the air conditioner relative to the heating of the main harmonic $(50 \mathrm{~Hz})$ of current is determined as follows.

As is known, the approximate value of the active value of the active power in the presence of the first and the higher to $40^{\text {th }}$ harmonics, is calculated for the formula, W

$$
P=P_{1}+\Delta P_{n}=I_{1}^{2} R+\sum_{n=2}^{40} I_{n}^{2} R .
$$

In general, the given formula (1) allows us to approximate the loading modes (W) in the electrical wiring, for example, the conditional group \#1 (Fig. 4), made by cop-

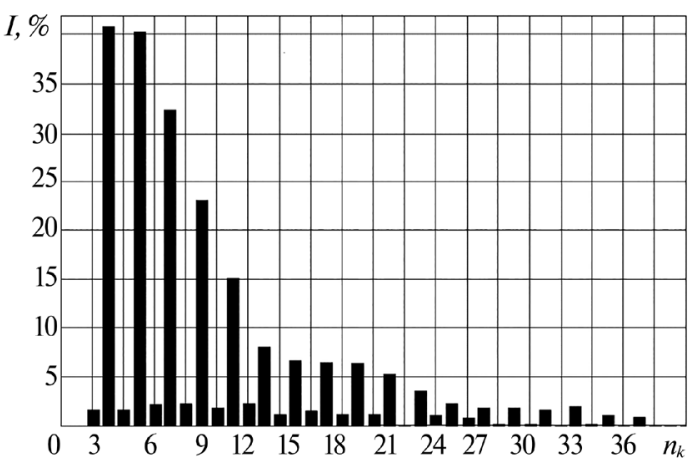

Fig. 3. Amplitude spectrum of harmonics of current load of a conditioner of series SENSEI ECO-i FTE-23MR

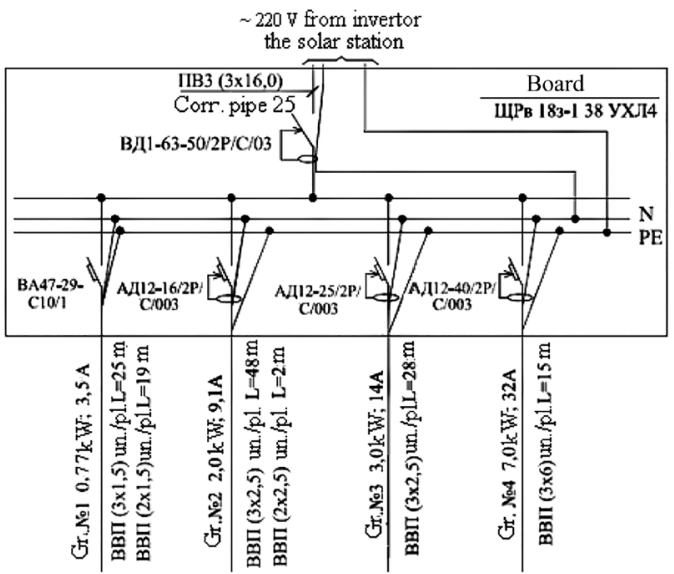

Fig. 4. Characteristic scheme of group networks with voltage of $220 \mathrm{~V}$ of the object 
per wire in the cross section of $2.5 \mathrm{~mm}^{2}, 5 \mathrm{~m}$ in length, $\rho=0.0074 \mathrm{Om} / \mathrm{m}$, from the electric shield to the air conditioner, under the influence of the $1^{\text {st }}(3.5 \mathrm{~A})$ and higher, up to the $25^{\text {th }}$ harmonic, as follows

$\left.\left[\begin{array}{c}0.42 \\
0.41 \\
0.33 \\
0.23 \\
0.15 \\
0.08 \\
0.052 \\
0.052 \\
0.052 \\
0.05 \\
0.04 \\
0.02\end{array}\right)^{2}\right] \cdot(0.0074 \cdot 5)=$\begin{tabular}{|r|r|}
\hline & 0 \\
\hline 0 & 0.023 \\
\hline 1 & 0.022 \\
\hline 2 & 0.014 \\
\hline 3 & $6.851 \cdot 10^{-3}$ \\
\hline 4 & $2.914 \cdot 10^{-3}$ \\
\hline 5 & $8.288 \cdot 10^{-4}$ \\
\hline 6 & $3.502 \cdot 10^{-4}$ \\
\hline 7 & $3.502 \cdot 10^{-4}$ \\
\hline 8 & $3.502 \cdot 10^{-4}$ \\
\hline 9 & $3.238 \cdot 10^{-4}$ \\
\hline 10 & $2.072 \cdot 10^{-4}$ \\
\hline 11 & $5.18 \cdot 10^{-5}$ \\
\hline
\end{tabular}

The final power from the occurrence of higher harmonics from the $2^{\text {nd }}$ to the $36^{\text {th }}$ will amount to $0.071 \mathrm{~W}$, which exceeds the rated current of $3.5 \mathrm{~A}$ for the fundamental harmonic by $7.6 \%$.

Simulation of the current dynamics in the standard group voltage networks in $220 \mathrm{~V}$ of any object will help to detect the additional heating of the wiring from the emergence of higher harmonics generated by the inverter, nonlinear electric receivers (Fig. 4).

As a rule, the standard electric network is executed by the brands of VVP $(B B \Pi)$ with copper zigzags of the corresponding section, which are laid under the plaster.

Mathematical models of differential equations describing electrical processes in circles by the action of the $1^{\text {st }}$ to the $40^{\text {th }}$ harmonics have the following form

$$
\left.\begin{array}{c}
e_{40.1}-R_{40.1} i_{2.1}-L_{40.1} \frac{d i_{40.1}}{d t}=u_{40.1} \\
R_{40.2} i_{40.2}-L_{40.2} \frac{d i_{40.2}}{d t}=u_{40.2} \\
\ldots \\
e_{40 n}-R_{40 n} i_{40 n}-L_{40 n} \frac{d i_{40 n}}{d t}=u_{40 n}
\end{array}\right\} ;
$$

where $R, L$ are active and inductive supports of the electrical network for individual harmonics and areas marked by the corresponding indices; $e, i, u$ are electromotive force, current and voltage for individual harmonics and areas marked with appropriate indexes.

As the inverter generates higher harmonics and available nonlinear electric receivers, the network will be heated further, which will increase the current in the circles by which the section of conductors, security devices, and other units will be selected [13].

The oscillogram of the load current of the solar station inverter by phase $\mathrm{A}$ in normal operating mode on a sunny day is shown in Fig. 5.

Measured with the help of the quality analyzer, the amplitude current spectrum in phase $A$ at the output of the HUAWEI SUN2000-36KTL inverter to the electricity meter is shown in Fig. 6.

Exceeding the conductor temperature relative to the environment will be represented by a differential equation

$$
I_{n}^{2} k_{J} R_{n}=C \frac{d J}{d t}+A J,
$$

where $k_{J}=1+\alpha J, \alpha$ is the temperature coefficient of resistance; $J$ is the temperature of overheating of the conductor; $R_{n}$ is resistance of the conductor by current of the $n^{\text {th }}$ harmonic at $20{ }^{\circ} \mathrm{C} ; C$ is thermal conductivity of the conductor; $A$ is the coefficient of heat transfer of the conductor heat to the environment, which according to all allowable values for the conductor has the form

$$
A=\frac{I_{\text {allow }}^{2} R_{\text {allow }}}{J_{\text {allow }}} .
$$

Taking into account the above, the time of heating the conductor is determined by the formula

$$
T_{0}=\frac{C}{A}=\frac{C J_{\text {allow }}}{I_{\text {allow }}^{2} R_{\text {allow }}} .
$$

On the basis of the values of the heating dynamics of the conductor with resistance $z$, for any time you can find the maximum averaged over 30 minutes. (half-hourly maximum), that is, the estimated load by the formula

$$
I_{p}=\sqrt{\frac{\left(1+\alpha J_{\text {allow }}\right) z}{1+\alpha J_{\text {allow }} \frac{z}{I_{\text {allow }}^{2}}}} .
$$

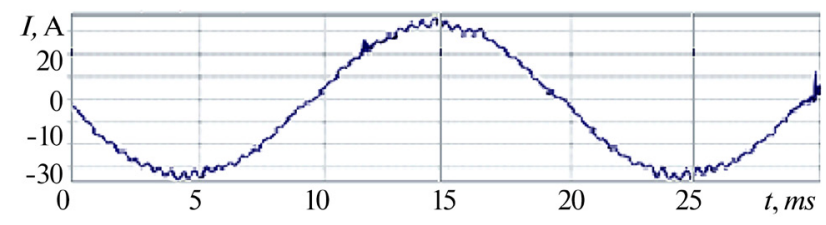

Fig. 5. Oscillogram of load current of the inverter by phase $A$

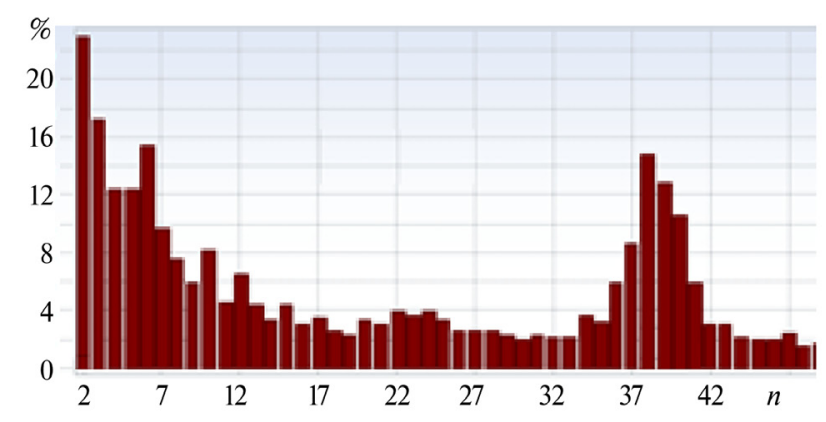

Fig. 6. Amplitude current spectrum in phase A at the output of the inverter HUAWEI SUN2000-36KTL 
The obtained values of each of the harmonics of current will allow the above method to determine the excess of the heating temperature of the wiring over the environment, that is, to find an additional increase in the calculated load on the electrical network, which depends on its parameters, the rate of return of heat by the conductor environment, the presence of nonlinear characteristics of the electrical receivers, and the properties of the power supply.

Measures to reduce distortion of sinusoidal current in the network. Reducing distortions is carried out by applying active, passive LC filters that are tuned to a certain order of harmonics, separate transformers with a winding connection $\Delta / Y$ with zero, which prevents the entry of $3^{\text {th }}$ harmonics into the secondary winding, the activation of magnetic synthesizers for protection against distortion, active air conditioners generating the harmonics of opposite signs.

The management of inverter systems that correct the work of various rows of solar station modules is improved. Improving the quality of electricity at the output of inverters is due to the use of advanced pulse-width modulation systems.

Reducing the effect of higher harmonics can occur due to the ordering of the electrical receivers with nonlinear characteristics, as well as the implementation of their supply by separate lines or from individual sources, etc.

Conclusions. The proposed methodology and experimentally obtained results of the research are the basis for evaluating the influence of solar station inverters, individual electrical receivers on increasing electric power losses due to the distortion of sinusoid current, the voltage causing negative and, in some cases, dangerous situations in electrical networks due to the generation of higher harmonics.

This will serve as the basis for developing an appropriate database of individual EPs for the properties of distortion of current, voltage and measures to improve the quality of electrical energy. An important direction for further scientific research on this topic is to estimate the magnitude of losses from higher harmonics not only in conductors of electrical networks, but also in power transformers, electric motors, electrical receivers elements, and power supply systems from renewable energy sources.

\section{Reference.}

1. Pivnyak, G. G. and Shkrabets, F. P., 2013. Alternative energy in Ukraine: monograph. Dnipropetrovsk: NGU. 2. Zhezhelenko, I. V., Shydlovskyi, A. K., Pivnyak, G. G. and Saienko, Yu. L., 2009. Electromagnetic compatibility in power supply systems [online]. Dnipropetrovsk: NGU. Available at: <http://eir.pstu.edu/handle/123456789/ 5461> [Accessed 15 November 2016].

3. Prakhovnik, A. V. Small energy: the updiffused generation in the systems ofenergy supply [pdf]. Kyiv: Osvita Ukrainy. Available at: <http: //energy.kpi.ua/files/ 2012_2/8-15.pdf> [Accessed 5 January 2017].

4. Lezhniuk, P., Vyshnevskyi, S. and Semeniuk, N. Modelling the load of electrical networks by cubic splines in adaptive SACs in advance [pdf]. Lviv: NU "Lvivska Politekhnika". Available at: <http://ena.lp.edu.ua:8080/ bitstream/ntb/ 35062/1/17_85 - 87.pdf $>$ [Accessed 7 December 2016].
5. Kumar, P. V., Maheswari, D. and Kumar, T. N., 2013. Power Quality Improvement for Grid Connected Photovoltaic System. Advanced Trends in Computer Science and Engineering, 2(2), pp. 23-28.

6. Bhim Singh, D. T. Shahani, and Arun Kumar Verma, 2012. Power Balance Theory Based Control of Grid Interfaced Solar Photovoltaic Power Generating System with Improved Power Quality. In: proc. for 2012 IEEE International Conference on Power Electronics, Drives and Energy Systems, Bengaluru, India, December 16-19, 2012 [online]. Available at: <https://www.researchgate.net/ publication/264309542_Power_Balance_Theory_ Based_Control_of_Grid_Interfaced_Solar_Photovoltaic_Power_Generating_System_with_Improved Power_Quality> [Accessed 15 November 2016].

7. Patricio Salmer'on and Salvador P. Litr'an. A Control Strategy for Hybrid Power Filter to Compensate FourWires Three-Phase Systems. IEEE Transactions on Power Electronics [online], 25(7). Available at: $<\mathrm{http}: / /$ ieeexplore. ieee.org/document/5419989/> [Accessed 22 January 2017]. 8. Kumar, A. and Singh, J., 2013. Harmonic Mitigation and Power Quality Improvement Using Shunt Active Power Filter. International Journal of Electrical, Electronics and Mechanical Controls, 2(2).

9. Renzhong, X., Lie, X. and Junjun, Zh., 2013. Design and Research on the LCL Filter in Three-Phase PV Grid-Connected Inverters. Computer and Electrical Engineering, 5(3), pp. 322-325.

10. Armstrong, M., Atkinson, D. J. and Johnson, C. M. Low Order Harmonic Cancellation in a Grid Connected Multiple Inverter System Via Current Control Parameter Randomization. IEEE Trans. Power Electronics [online], 20(4), pp. 885-892. Available at: <https:// www.researchgate.net/publication/3280733_Low_Order_Harmonic_Cancellation_in_a_Grid_Connected_ Multiple_Inverter_System_Via_Current_Control_Parameter_Randomizationhttp://ieeexplore.ieee.org/ document/5419989/> [Accessed 7 February 2017].

11. Bondarchuk, A.S., 2015. In-house electrical power supply. Kyiv: Osvita Ukrayiny.

12. Razumniy, Y. T., Rukhlov, A. V., Prokuda, V. M. and Rukhlova, N.Y., 2014. Effective use of electric power and fuel. Dnipropetrovsk: NGU.

13. Burbelo, M. J., Biryukov, O. O. and Melnychuk, L. M., 2011. Power supply systems. Elements of the theory and examples of calculations. Vinnytsia: VNTU.

Мета. Оцінити величину впливу струмів вищих гармонік на електричне навантаження сонячної станції, об’єкта з нелінійними електроприймачами, що отримують електроенергію від інвертора мережевої сонячної електростанції.

Методика. Експериментальним вимірюванням і моделюванням процесів в електричній мережі виявлено вміст у ній вищих гармонік від інвертора сонячної електростанції, нелінійних електроприймачів об’єкта, визначена величина їх впливу на розрахункове навантаження.

Результати. Оцінена глибина впливу струмів вищих гармонік від інвертора сонячної електростанції, нелінійних електроприймачів на величину елек- 
тричного навантаження за рахунок додаткового нагрівання струмовідних частин, яке повинно враховуватись за конкретних умов.

Наукова новизна. Полягає в експериментальному дослідженні спектрів вищих гармонік інвертора мережевої сонячної станції, окремих нелінійних електроприймачів, ступінь їх впливу на збільшення втрат електроенергії в електричних мережах, що викликають додаткове нагрівання в порівнянні з протіканням синусоїдального струму.

Практична значимість. Отримані експериментальним вимірюванням спектри вищих гармонік інверторів мережевих сонячних електростанцій, електроприймачів, об'єктів можуть служити інформацією для формування відповідних баз даних. Це може використовуватися для визначення розрахункового електричного навантаження, що сприятиме запобіганню перегрівання електричних мереж.

Ключові слова: мережева сонячна електростанція, інвертор, вищі гармоніки, нелінійні електроприймачі, розрахункове навантаження

Цель. Оценка величины влияния токов высших гармоник на электрическую нагрузку солнечной станции, объекта с нелинейными электроприемниками, которые получают электроэнергию от инвертора сетевой солнечной электростанции.

Методика. Экспериментальным измерением и моделированием процессов в электрической сети выявлено содержание в ней высших гармоник от инверто- ра сетевой солнечной электростанции, нелинейных электроприемников объекта, определена величина их влияния на расчетную электрическую нагрузку.

Результаты. Оценена степень влияния токов высших гармоник от инвертора сетевой солнечной электростанции, нелинейных электроприемников на величину электрической нагрузки за счет дополнительного нагревания токопроводящих частей, что должно учитываться при конкретных условиях.

Научная новизна. Состоит в экспериментальном исследовании спектров высших гармоник инвертора сетевой солнечной станции, отдельных нелинейных электроприемников, степень их влияния на увеличение потерь электроэнергии в электрических сетях, которые вызывают дополнительный нагрев по сравнению с протеканием синусоидального тока.

Практическая значимость. Полученные экспериментальным измерением спектры высших гармоник инверторов сетевых солнечных электростанций, электроприемников, объектов могут служить информацией для формирования соответствующих баз данных. Это может использоваться для определения расчетной электрической нагрузки, что будет способствовать предупреждению перегрева электрических сетей.

Ключевые слова: сетевая солнечная электростанция, инвертор, высшие гармоники, нелинейные электроприемники, расчетная нагрузка

Рекомендовано до публікації докт. техн. наук В.В. Римшею. Дата надходження рукопису 04.12.16. 